\title{
RESENHA
}

\section{Geo-grafias - Movimientos sociales, Nuevas territorialidades y Sustentabilidad}

\author{
CARLOS WALTER PORTO GONÇALVES \\ Siglo Veintiuno Editores. México. 2001
}

“Geo-grafias" de Carlos Walter Porto Gonçalves é a reunião de um texto teorizando a geografia como leitura e um texto flagrando-a como realidade do mundo. A palavra emprestada à natureza significa-a como território e espaço. É o ponto de partida para a análise da Amazônia como conflitos de territorialidades. E da Amazônia como Amazônias. Conflito entre a Amazônia-região inventada pelos seringalistas e a Amazônia-pluralidade inventada pelas diferentes culturas que vai dos seringueiros e passa pelos campesinato ao indigenato.

O livro desvela o signo tomado pelo real e o real que não se revela por meio desse signo. A Amazônia é plural: há a Amazônia do seringalista, a Amazônia dos camponeses (já aí muitas) e a Amazônia das comunidades indígenas (infinidade de Amazônias). Retrada em seu recorte uma realidade ainda hohje escondida do Brasil: um país absolutamente multinacional: há a nação brasileira, a nação yanomami, a nação...

É um livro de um enfoque genuíno e muito próprio. Propriedade de um campo de saber que, estando por se recriar, possui por isto mesmo a riqueza de muitos possíveis caminhos. Basta a inteligência e a ousadia criativa. $\mathrm{E}$ isto num país de muitos criadores de novidades de enfoques na geografia. Na de Carlos Walter, pode-se ver um Wittgenstein, Morin e Bourdieu, trilhados de uma maneira surpreendentemente impensada.

$\mathrm{O}$ homem nomeia a natureza. E a natureza significada vira território ("O homem nomeia a árvore; e a árvore se faz corpo”, nas palavras do prefaciador Enrique Leff). Casamento da natureza e da palavra, o território é um magma de significações, e o 
lugar da alteridade. E é isto a reserva extrativista. Mais que um projeto florestal de reforma agrária, é um projeto de uma sociedade ecologicamente apontada para uma história dos homens com diferenças e não desigualdades de classes. Assim, da natureza significada pelo latifúndio, o livro de Carlos Walter mostra como nasce a natureza amazônica ressignificada pelo verbo do serigueiro. Num texto que saí de sua tese de doutoramento, Carlos Walter acompanha e participa das classes em luta (mais que as lutas de classes, na sua expressão) por uma sociedade de uma história nova.

$\mathrm{Na}$ linha de outros livros do autor, "Geo-grafias" junta a proposta de enfoque de Carlos Walter que encontramos em Paixão da Terra e (Des)Caminhos do Meio Ambiente, e no recente Amazônia, Amazônias.

É uma bela proposta de uma outra geografia. Se a geografia que temos serve à afirmação da identidade através da comparação que suprime a diferença, a geografia de Carlos Walter serve à diferença através da afirmação da identidade. Uma dialética sem supressões da diversidade pela unidade. Talvez assim possa ser dito.

Publicado por uma das maiores editoras do mundo, poucos podem ter acesso todavia ao livro. Pessoanamente vale a pena o esforço de consegui-lo, enquanto uma editora inteligente não toma a inciativa de publicá-lo para a facilidade do acesso entre nós.

(Ruy Moreira) 